\title{
Why should Business schools teach blockchain technology? The case of Botswana Accountancy College
}

\author{
Wilbert R. Mutoko, Senior Lecturer \\ Tapiwa Gande, Portfolio Manager \\ School of Business and Leisure, \\ Botswana Accountancy College, Gaborone, Botswana
}

Doi:10.19044/esj.2021.v17n32p349

Submitted: 14 June 2021

Accepted: 09 September 2021

Published: 30 September 2021
Copyright 2021 Author(s)

Under Creative Commons BY-NC-ND

4.0 OPEN ACCESS

Cite As:

Mutoko W.R. \& Gande T. (2021). Why should Business schools teach blockchain technology? The case of Botswana Accountancy College. European Scientific Journal, ESJ, 17 (32), 349. https://doi.org/10.19044/esj.2021.v17n32p349

\section{Abstract}

In this digital era, tertiary education institutions students need to be acquainted with the latest technology such as blockchain, to equip them for industry readiness. There is a paradigm shift in blockchain technology. Thus, business schools would do well to teach tertiary students about blockchain technology which in turn can help them to solve real-life and industry challenges efficiently and effectively. This paper aimed to investigate tertiary students' awareness and competency of blockchain technology and cryptocurrency. The paper's objectives were to assess students' level of knowledge on blockchain, to explore students' depth of awareness and competency on bitcoin and altcoins, and to recommend steps that business schools can take to teach students on blockchain. In July 2018, a closed-ended questionnaire was distributed to 266 students studying Business and Leisure related programs at Botswana Accountancy College, School of Business \& Leisure. Quota-randomized system was used to allow participation of respondents that are more entrepreneurially aligned according to course content and aims. The data was analyzed using Statistical Package for Social Sciences (SPSS). The study findings revealed that most students are challenged or know little about blockchain, let alone Bitcoin and Altcoins. Thus, business schools should take it upon themselves to educate not only students, but the community at large about blockchain to bring awareness. Furthermore, business schools such as BAC should make policies that allow 
them to embed blockchain technology into their teaching/learning strategies, record-keeping, and information management.

Keywords: Blockchain technology, Cryptocurrency, Botswana Accountancy College, Bitcoin, tertiary students, business schools

\section{Introduction}

There is an ongoing debate as to whether institutions of higher learning are still relevant (Bracey, 2017, Willcocks, 2020; Wiklund, Wright and Zahra, 2019). This debate gets worse when it comes to business schools (Busher, Choudhury, Thomas, Harris, 2017; Blackman, 2017). One would wonder whether business schools are playing a significant role in preparing graduates for the world of work and entrepreneurship. Botswana is not exempt from this debate in question.

Gone are the days when teaching and learning dwelt on traditional methods and strategies. In today's dynamic world, there is a need for practitioners and students to embrace technology. This paper looks at how business schools could acquaint students with knowledge on block chain technology. A blockchain is a distributed database of records of all transactions, or public ledger of digital events that have been executed and shared among participating parties. Each transaction in the public ledger is verified by consensus of most of the participants (Crosby, Pattanayak, Verma, \& Kalyanaraman, 2016; Deshpande, Stewart, Lepetit, \& Gunashekar, 2017). Block chain technology can also be defined as mutual distributed ledgers (Mainelli \& Smith, 2015; Korpela, Hallikas, \& Dahlberg, 2017; Wüst \& Gervais, 2018).

In this digital era, tertiary students need to be acquainted with the latest technology such as blockchain, to equip them for industry readiness (Luhanga, 2020). Thus, business schools would do well to teach tertiary students about blockchain technology which in turn can help them to solve real-life and industry challenges efficiently and effectively. This paper aims to investigate tertiary students' awareness and understanding of blockchain technology and cryptocurrency. The paper's objectives are to assess students' level of knowledge on blockchain, to explore students' depth of awareness and competency on bitcoin and altcoins, and to recommend steps that business schools can take to teach students on blockchain.

\section{Definition of Terms Blockchain}

Blockchain technology is credited for transformation of the financial services industry into a new level of efficiency and effectiveness (Luhanga, 2020). Blockchain has gained traction since 2008 when a person (or group of 
persons) Satoshi Nakamoto, to serve as a public transaction ledger of the cryptocurrency bitcoin (Lizcano, Lara, White, and Aljawarneh, 2020; Wired Horizon, 2016). A blockchain is a decentralized, distributed, and public digital ledger that is used to record transactions across many computers so that any involved record cannot be changed retroactively, without the alteration of all subsequent blocks (Lizcano, Lara, White \& Aljawarneh, 2020; Wired Horizon, 2016).

Blockchain is a list of records called blocks, linked together by cryptography (Kumaresh, 2021). Cryptography refers to the art and/or science of keeping information secret through transforming it (encrypting it) into an unreadable format known as cypher text; and decryption, which is the reverse, that is, moving from the unintelligible ciphertext back to plaintext (Luhanga, 2020; Fanning \& Centers, 2016). A cypher system is also known as a cryptosystem. Blockchain consists of peer-to-peer networking of computers, that is, 'participating computers are directly linked to each other through the Internet, without any central controller' (Kumaresh, 2021; Batkins \& Brannon, 2013).

A blockchain consists of three main, complementary parts: a shared state, a set of rules for updating state via blocks and a trust (Luhanga, 2020; Mainelli \& Smith, 2015). Blockchain has various benefits that include safe shopping, cutting off the middleman hence increasing profits for musicians and other businesspeople, no centralization, and unnecessary controls, whatever has been recorded is permanent which can be good for school records and company records (Kumaresh, 2021; Batkins \& Brannon, 2013; Ye, Ojukwu, Hsu, and $\mathrm{Hu}, 2020$; Kakushadze and Yu, 2019). However, although blockchain is considered disruptive technology, there are critics who judge the technology as over-hyped (Lizcano, Lara, White, and Aljawarneh, 2020; Risius \& Spohrer, 2017). Some critics argue that some duties should still be done by humans, without leaving all trust to machines. Nevertheless, the security and efficiency of blockchain far outweighs the fears. That is why banks, the non-banking fraternity, hospitals, schools, and government departments are warming up to the use of blockchain (Luhanga, 2020).

\section{Bitcoin}

Bitcoin is a private, non-centrally managed "cryptocurrency" those users create and exchange over the Internet via an open-source protocol (Lemieux, 2013, pg.1).

According to Nakamoto (2008) "A purely peer-to-peer version of electronic cash would allow online payments to be sent directly from one party to another without going through a financial institution. Digital signatures provide part of the solution, but the main benefits 
are lost if a trusted third party is still required to prevent doublespending."

Some people argue that Satoshi Nakamoto is not one person, but it is an acronym that represents: The invention of blockchain for bitcoin gave birth to arguably the first decentralized digital currency without government control or banking fraternity control (Lizcano, Lara, White, \& Aljawarneh, 2020). However, at this stage, it is difficult to know whether Satoshi is an individual or a group of people. Nevertheless, the technology behind bitcoin cannot be underrated. Bitcoins are divisible units. The smallest divisible unit of a bitcoin is called a Satoshi, and it is about one hundred-millionth of a bitcoin (Ye, Ojukwu, Hsu, \& Hu, 2020; Kakushadze \& Yu, 2019). This is a digital currency that exists only virtually on the network. Bitcoins can be made through "mining"), which can be done by anybody with enough mathematical and computer knowledge, requires a lot of computer power, part of which is simultaneously used to process and verify Bitcoin's encrypted transactions (Lemieux, 2013, pg.1; Kumaresh, 2021; Batkins \& Brannon, 2013).

Anybody who just wants to buy, sell, or store existing bitcoins can easily create his own Bitcoin account by downloading a version of the client software; there are also less computer-literate methods of using the system (Ye, Ojukwu, Hsu, \& Hu, 2020; Kakushadze and Yu, 2019). Some people manage their account using just a smartphone. With an account, one's computer or device becomes part of the peer-to peer network. It therefore goes without saying that digital money is the new currency. Cryptocurrency is going nowhere. Large corporations and some governments are adopting use of blockchain technology and cryptocurrencies (Ølnes and Knutsen, 2020; Luhanga, 2020).

\section{Altcoin}

Alt coins are other cryptocurrencies that came after bitcoin (Nguyen, Nguyen, Nguyen, and Nguyen, 2019; Lizcano, Lara, White, and Aljawarneh, 2020). Alt coins are all other cryptocurrencies other than bitcoin. Examples of well-known altcoins include Etherium (ETH), Monero (XMR), Cardano (ADA), Bitcoin Cash (BCH), Tether (USDT), Binance Coin (BNB), Litecoin (LTC), Stella (XLM), Doge Coin (Doge), and many others (Ye, Ojukwu, Hsu, and $\mathrm{Hu}, 2020$; Kakushadze and $\mathrm{Yu}, 2019)$.

\section{Literature Review}

Bitcoin and altcoins are transforming the world of money and solutions provision. The literature review looks at the role of business schools in teaching students, and the relevant theoretical frameworks (Ølnes \& Knutsen, 2020). While bitcoin and the altcoins have gained momentum over the years, 
some critics say that cryptocurrencies are not going far (Bheemaiah, 2015; Wamba, Kamdjoug, Bawack and Keogh, 2020).

Dettling (2018) postulated that business schools should develop syllabus to teach about blockchain and cryptocurrencies (Crandall, 2019; Lizcano, Lara, White, and Aljawarneh, 2020). The key issues to be asked during the development of the syllabus include key research topics in blockchain, impact of blockchain, and the influence of bitcoin in the future.

Furthermore, Bheemaiah (2015) asserted that financial institutions, central banks, and governments are increasingly accepting the use of blockchain and cryptocurrency. On the other hand, Negash \& Thomas (2019) postulated a 7-scenario design for teaching blockchain technology to nontechnical students. The design identifies key learning objectives as well as administrative and infrastructure component solutions that can be used by others seeking to teach such a course.

Wamba, Kamdjoug, Bawack and Keogh (2020) carried out a systematic review of five top academic databases and case studies in the supply chain industry and they developed a classification framework and used it to perform an analysis of 141 articles from five top academic databases as a baseline study. Their findings revealed that blockchain, bitcoin and altcoins are evolving, and organizations are embracing them for competitive advantage. The authors concluded that organizations need to leverage research on these technologies to better understand them, optimize their business strategies, and develop critical insights for decision-making. The current study therefore wishes to close the gaps of awareness and competency in blockchain technology and cryptocurrencies among students and graduates in Botswana.

On the other hand, Luhanga (2020) carried out a study in Tanzania which suggested that business schools should teach blockchain technology. According to the study, block chain touches a range of disciplines including accounting, mathematics, finance, law, insurance, banking, electrical engineering, business, economics, and computer science. Furthermore, the author posited that the widespread deployment of blockchain technology in these industries would, most probably therefore precede its widespread deployment in other sectors of the economy. Finance, banking, and insurance are areas within the prime terms of reference of business schools. The study therefore concluded that the introduction of education on block chain technology in business schools would be the first step, which business schools could take in producing tech savvy business school graduates who are required by the digital economy of the emerging Fourth Industrial Revolution. This will improve awareness and competency among students and graduates alike, which improves industry performance by using modern technology.

Furthermore, according to a study by Ølnes and Knutsen (2020) in Norway, most of the Norwegian universities acknowledge blockchain 
technology as an important new technology that needs to be incorporated into the existing study programs in economics. Some universities in Norway have incorporated block chain technology into their undergraduate and postgraduate curricula. However, some of the responses may indicate a lack of understanding of the tight and crucial interconnection between the technology and the currency. Without this understanding, it is difficult to design interdisciplinary courses. However, there are also respondents that acknowledge the need for a disciplinary approach to this topic. More so, the plans for teaching this new technology vary from a modest incorporation into existing courses to establishing stand-alone courses. Some of the universities are also trying to establish joint courses with other faculties to bridge technology and economics. The study concluded that there is a demand for education in this field, but also that the students expect and hope for further progression from an introductory course into fully developed study programs. However, there is still a challenge to better integrate the different disciplines in blockchain technology and to remove unnecessary barriers.

Now more than ever before, it is crucial for business schools to introduce teaching of blockchain technology and cryptocurrencies. This will help graduates to be ready to embrace blockchain changes. Furthermore, the communities surrounding the tertiary institutions can be taught short courses on blockchain and cryptocurrency.

\section{Research Methodology}

The research adopted a positivist philosophy and a deductive approach with a quantitative strategy (Saunders et al, 2019). To this end, data was collected once, using a cross-sectional time-horizon employing a questionnaire. The target population was Botswana Accountancy College (BAC) students in the School of Business \& Leisure (SBL). While BAC delivers degrees at undergraduate and postgraduate Masters including short courses in computing, project management and professional accountancy courses such as ACCA, CIMA, BICA among others, in other three other schools/ faculties besides SBL, the students targeted as the population for the study were limited to the BACs School of Business \& Leisure (SBL), which operates in two geographic locations, the capital city of Botswana, Gaborone and the second largest city, Francistown, about 430 kilometers to the north of Gaborone. The BAC's School of Business delivers business and leisure degree courses covering Business Management (BM), Entrepreneurship and Business Leadership (EBL), International Tourism Management (ITM) and International Finance and Banking (IFB).

As of December 2017, the population of students in the above programmes was about 752 students. The table below and further notes outline some of the sampling and data-collection procedures and decisions. 
Table 1: Population of students in the School of Business \& Leisure

\begin{tabular}{|l|c|c|c|c|}
\hline & \multicolumn{4}{|c|}{ Number of students } \\
\hline Year/ level of study > & Year 1 & Year 2 & Year 3 & Total \\
\hline Programme of study & & & & \\
\hline Business Management & 16 & 59 & 116 & $\mathbf{1 9 1}$ \\
\hline Entrepreneurship \& Business Leadership & 77 & 65 & 60 & $\mathbf{2 0 2}$ \\
\hline International Finance \& Banking & 63 & 51 & $\#$ & $\mathbf{1 1 4}$ \\
\hline International Tourism Management \#\# & 85 & 78 & 82 & $\mathbf{2 4 5}$ \\
\hline Total & $\mathbf{2 4 1}$ & $\mathbf{2 5 3}$ & $\mathbf{2 5 8}$ & $\mathbf{7 5 2}$ \\
\hline
\end{tabular}

\section{Notes}

- The programme of study was newly introduced and did not have final (year students at this time).

- This programme is also delivered in a second location, the second largest city in Botswana called Francistown. The number of students at this location is not factored out as it has a minimal impact on the population and sample.

- Students who would have failed, dropped out or are repeating a module or two in the degree/ programmes of study are in single digit estimates across the programmes and the effects of these were not catered for as the research was intended to be all-inclusive.

The sampling, using a quota-randomized system to allow wide participation across programmes and levels of study, was done in July 2018. The quota sampling system was applied across programmes of study in that all programmes (in Gaborone) were allowed to participate, but also randomized in that no restriction was placed on the level of study. Completed closed-ended questionnaires were collected from 266 students studying Business and Leisure related programs at Botswana Accountancy College School of Business \& Leisure as outlined. This represented a response rate of $35 \%$ which was considered acceptable. The quota sampling was used to allow participation of respondents that are more entrepreneurially aligned according to course content and aims; thus, it was mostly final year students that participated. This could indicate entrepreneurial intent or openness to exploring new ways of making a living after degree course completion. One course that is also delivered in the School of Business and Leisure, the Accounting \& Finance degree programme was not included because it is technical and does not lend itself easily to entrepreneurial content in the course. The data was analyzed using the Statistical Package for Social Sciences (SPSS) software.

\section{Discussion of Results}

This section discusses results of the findings. 
Table 2: Descriptive Statistics

\begin{tabular}{|c|c|c|c|c|c|}
\hline & $\mathrm{N}$ & Minimum & Maximum & Mean & Std. Deviation \\
\hline Gender & 266 & 0 & 2 & 1.35 & .531 \\
\hline Age & 266 & 0 & 4 & 1.79 & .635 \\
\hline Level of Study & 266 & 0 & 4 & 3.56 & 637 \\
\hline Program of Study & 266 & 1 & 4 & 2.94 & 1.159 \\
\hline Level of understanding & 266 & 0 & 5 & 1.67 & .910 \\
\hline Knowledge of Bitcoin & 266 & 0 & 5 & 2.29 & .901 \\
\hline Explaining blockchain & 266 & 1 & 4 & 1.41 & .711 \\
\hline Trading in bitcoin & 266 & 1 & 2 & 1.05 & .224 \\
\hline Keep, trade or both & 266 & 0 & 5 & .67 & 1.378 \\
\hline Difference bitcoin \& altcoins 1 & 266 & 0 & 2 & 1.81 & .419 \\
\hline $\begin{array}{l}\text { Difference bitcoin \& altcoins } 2 \\
\text { Option } 1\end{array}$ & 266 & 0 & 1 & .08 & .264 \\
\hline $\begin{array}{l}\text { Difference bitcoin \& altcoins } 2 \\
\text { Option } 2\end{array}$ & 266 & 0 & 1 & .04 & .191 \\
\hline $\begin{array}{l}\text { Difference bitcoin \& altcoins } 2 \\
\text { Option } 3\end{array}$ & 266 & 0 & 1 & .00 & .061 \\
\hline $\begin{array}{l}\text { Difference bitcoin } \& \text { altcoins } 2 \\
\text { Option } 4\end{array}$ & 266 & 0 & 1 & .08 & .270 \\
\hline $\begin{array}{l}\text { Difference bitcoin \& altcoins } 2 \\
\text { Option } 5\end{array}$ & 266 & 0 & 0 & .00 & .000 \\
\hline $\begin{array}{l}\text { Difference bitcoin \& altcoins } 2 \\
\text { Option } 6\end{array}$ & 266 & 0 & 1 & .02 & .136 \\
\hline Keen to learn & 266 & 0 & 4 & 2.71 & 1.080 \\
\hline Starting investment & 266 & 0 & 5 & 1.51 & 1.157 \\
\hline Blockchain solution & 266 & 0 & 4 & 2.50 & .961 \\
\hline Any organization & 266 & 0 & 2 & 1.08 & .339 \\
\hline Future of blockchain & 266 & 0 & 3 & 1.97 & .824 \\
\hline Valid N (listwise) & 266 & & & & \\
\hline
\end{tabular}

The table shows the different aspects of the questionnaire.

Table 3: Gender

\begin{tabular}{rcr|r|r|r} 
& \multicolumn{2}{c}{} & & \multicolumn{2}{c}{$\begin{array}{c}\text { Cumulative } \\
\text { Percent }\end{array}$} \\
\hline Valid & Frequency & Percent & Valid Percent & 2.6 \\
\cline { 2 - 6 } & 0 & 7 & 2.6 & 2.6 & 62.0 \\
\cline { 2 - 6 } & Female & 158 & 59.4 & 59.4 & 100.0 \\
\cline { 2 - 6 } & Male & 101 & 38.0 & 38.0 & \\
\cline { 2 - 6 } & Total & 266 & 100.0 & 100.0 & \\
\hline
\end{tabular}

Table 3 shows that more female students $59.4 \%$ took part in the study compared to male students $38 \%$. 
Table 4: Age

\begin{tabular}{rcr|r|r|r} 
& & & & \multicolumn{2}{c}{$\begin{array}{c}\text { Cumulative } \\
\text { Percent }\end{array}$} \\
\hline Valid & Frequency & Percent & Valid Percent & .4 \\
\cline { 2 - 6 } & 0 & 1 & .4 & .4 & 32.0 \\
\cline { 2 - 6 } & $<20$ years & 84 & 31.6 & 31.6 & 89.5 \\
\cline { 2 - 6 } & $21-25$ years & 153 & 57.5 & 57.5 & 99.6 \\
\cline { 2 - 6 } & $>25$ years & 27 & 10.2 & 10.2 & 100.0 \\
\hline & 4 & .4 & .4 & \\
\hline
\end{tabular}

Table 4 depicts that most of the students that participated in the study (57.5\%) were aged between 21-25 years. This is because most students in university are around that age group.

Table 5: Level of Study

\begin{tabular}{rrr|r|r|r} 
& & & & \multicolumn{2}{c}{ Cumulative } \\
& \multicolumn{2}{c}{ Frequency } & Percent & Valid Percent & \multicolumn{1}{c}{ Percent } \\
\hline Valid & 0 & 3 & 1.1 & 1.1 & 1.1 \\
\cline { 2 - 6 } & Year 1 & 3 & 1.1 & 1.1 & 2.3 \\
\cline { 2 - 6 } & Year 2 & 98 & 36.8 & 36.8 & 39.1 \\
\cline { 2 - 6 } & Year 3 & 162 & 60.9 & 60.9 & 100.0 \\
\hline & Total & 266 & 100.0 & 100.0 & \\
\hline
\end{tabular}

According to Table 5, the year threes (final year) students were most of the participants. This is probably because final year students are about to leave school, hence they are keen to know what is happening in the industry. Thus, they decide to take part in the research.

Table 6: Program of Study

\begin{tabular}{|c|c|c|c|c|c|}
\hline & & & & & \\
\hline & & Frequency & Percent & Valid Percent & $\begin{array}{l}\text { ative } \\
\text { Percent }\end{array}$ \\
\hline \multirow[t]{5}{*}{ Valid } & Business Management & 48 & 18.0 & 18.0 & 18.0 \\
\hline & $\begin{array}{l}\text { Entrepreneurship \& Business } \\
\text { Leadership }\end{array}$ & 43 & 16.2 & 16.2 & 34.2 \\
\hline & $\begin{array}{l}\text { International Finance \& } \\
\text { Banking }\end{array}$ & 53 & 19.9 & 19.9 & 54.1 \\
\hline & $\begin{array}{l}\text { International Tourism } \\
\text { Management }\end{array}$ & 122 & 45.9 & 45.9 & 100.0 \\
\hline & Total & 266 & 100.0 & 100.0 & \\
\hline
\end{tabular}

As shown in Table 6, the programmes involved in the study were Business Management, Entrepreneurship \& Business Leadership, International Finance \& Banking, and International Tourism Management. 
Of all the programmes, the highest participants were from International Tourism Management (45.9\%), followed by International Banking \& Finance (19.0\%), Business Management (18.0\%), and Entrepreneurship \& Business Leadership at 16.2\%.

Table 7: Level of understanding blockchain

\begin{tabular}{cll|l|l|l} 
& & & & & Cumulative \\
& & Frequency & Percent & Valid Percent & Percent \\
\hline \multirow{5}{*}{ Valid } & 0 & 2 & .8 & .8 & .8 \\
\cline { 2 - 6 } & Nil & 147 & 55.3 & 55.3 & 56.0 \\
\cline { 2 - 6 } & Very minimal & 68 & 25.6 & 25.6 & 81.6 \\
\cline { 2 - 6 } & Good & 39 & 14.7 & 14.7 & 96.2 \\
\cline { 2 - 6 } & Very Good & 7 & 2.6 & 2.6 & 100.9 \\
\hline & Excellent & 3 & 1.1 & 1.1 & \\
\hline & Total & 266 & 100.0 & 100.0 & \\
\hline
\end{tabular}

Table 7 depicts that many students $(55.3 \%)$ know nothing about blockchain, followed by $25.6 \%$ that have very minimal knowledge of the subject being researched on. This is a clear sign that most students have no idea of blockchain. This is supported by Ølnes and Knutsen (2020) whose study in Norway mentioned that most of the Norwegian universities acknowledge blockchain technology as an important new technology that needs to be incorporated into the existing study programs in economics. Hence, some universities in Norway have incorporated block chain technology into their undergraduate and postgraduate curricula.

Table 8: Knowledge of Bitcoin

\begin{tabular}{ccr|r|r|r} 
& & & & \multicolumn{2}{c}{$\begin{array}{c}\text { Cumulative } \\
\text { Percent }\end{array}$} \\
\hline Vali & Frequency & Percent & Valid Percent & .4 \\
\cline { 2 - 6 } $\mathrm{d}$ & \multicolumn{1}{c}{ Nil } & 1 & .4 & .4 & 16.9 \\
\cline { 2 - 6 } & Very minimal & 125 & 16.5 & 16.5 & 63.9 \\
\cline { 2 - 6 } & Good & 73 & 27.4 & 47.0 & 91.4 \\
\cline { 2 - 6 } & Very Good & 18 & 6.8 & 27.4 & 98.1 \\
\cline { 2 - 6 } & Excellent & 5 & 1.9 & 1.9 & 100.0 \\
\hline & Total & 266 & 100.0 & 100.0 & \\
\hline
\end{tabular}

Table 8 depicts that many students $(47.0 \%)$ have minimal knowledge of bitcoin. Unlike knowledge of blockchain (14.7\%) in table 7, there is a higher percentage of participants that have a good knowledge of bitcoin $(27.4 \%)$. This is a clear sign that more students have minimal knowledge about bitcoin than blockchain. 
Table 9: Explaining blockchain

\begin{tabular}{rcr|r|r|r} 
& & & & \multicolumn{2}{c}{$\begin{array}{c}\text { Cumulative } \\
\text { Percent }\end{array}$} \\
\hline Valid & Frequency & Percent & Valid Percent & 70.3 \\
\cline { 2 - 6 } & No & 187 & 70.3 & 70.3 & 91.4 \\
\cline { 2 - 6 } & Probably & 56 & 21.1 & 21.1 & 97.7 \\
\cline { 2 - 6 } & Yes & 17 & 6.4 & 6.4 & 100.0 \\
\hline & Very much so & 6 & 2.3 & 2.3 & \\
\hline
\end{tabular}

Participants were asked whether they could explain blockchain to others. Table 9 shows that $70.3 \%$ could not explain blockchain. This shows that college students need to be taught about blockchain technology as postulated by (Ølnes and Knutsen 2020).

Table 10: Trading in bitcoin

\begin{tabular}{rcr|r|r|r} 
& & & & \multicolumn{2}{c}{$\begin{array}{c}\text { Cumulative } \\
\text { Percent }\end{array}$} \\
\hline Valid & Frequency & Percent & Valid Percent & 94.7 \\
\cline { 2 - 6 } & No & 252 & 94.7 & 94.7 & 100.0 \\
\cline { 2 - 6 } & Maybe & 14 & 5.3 & 5.3 & \\
\hline
\end{tabular}

Participants were asked whether they have ever bought or traded in bitcoin. Table 10 shows that $94.7 \%$ of the participants had never traded or bought bitcoin. This suggests that while participants knew something about bitcoin, they had never been active in trading it or buying it.

Table 11: Keep, trade or both

\begin{tabular}{cll|l|l|l} 
& & & Valid & Cumulative \\
& & Frequency & Percent & Percent & Percent \\
\hline \multirow{5}{*}{ Valid } & 0 & 207 & 77.8 & 77.8 & 77.8 \\
\cline { 2 - 6 } & To Keep & 5 & 1.9 & 1.9 & 79.7 \\
\cline { 2 - 6 } & To Trade & 20 & 7.5 & 7.5 & 87.2 \\
\cline { 2 - 6 } & Both Keeping and trading & 14 & 5.3 & 5.3 & 92.5 \\
\cline { 2 - 6 } & For transactions & 10 & 3.8 & 3.8 & 96.2 \\
\cline { 2 - 6 } & Other & 10 & 3.8 & 3.8 & 100.0 \\
\hline & Total & 266 & 100.0 & 100.0 & \\
\hline
\end{tabular}

Participants were asked whether they had ever bought bitcoin to keep, to trade, or both, and for transactions. $77.8 \%$ said that they had never done any of the above. This shows that most participants have no experience with both investing in and trading in bitcoin. 
Table 12: Difference bitcoin and altcoins

\begin{tabular}{|c|c|c|c|c|c|}
\hline & & Frequency & Percent & Valid Percent & $\begin{array}{l}\text { Cumulative } \\
\text { Percent }\end{array}$ \\
\hline \multirow[t]{4}{*}{ Valid } & 0 & 3 & 1.1 & 1.1 & 1.1 \\
\hline & Yes & 44 & 16.5 & 16.5 & 17.7 \\
\hline & No & 219 & 82.3 & 82.3 & 100.0 \\
\hline & Total & 266 & 100.0 & 100.0 & \\
\hline
\end{tabular}

Participants were asked whether they understood the difference between bitcoin and altcoin. $82.3 \%$ of the participants said that they could not distinguish between the two.

This is again an indication that the participants need to be taught on altcoins and bitcoin.

Table 13: Difference bitcoin \& altcoins 2 Option 1

\begin{tabular}{ccr|r|r|r} 
& & Frequency & Percent & Valid Percent & \multicolumn{2}{c}{$\begin{array}{c}\text { Cumulative } \\
\text { Percent }\end{array}$} \\
\hline Valid & No & 246 & 92.5 & 92.5 & 92.5 \\
\cline { 2 - 6 } & Ethereum & 20 & 7.5 & 7.5 & 100.0 \\
\cline { 2 - 6 } & Total & 266 & 100.0 & 100.0 & \\
\hline
\end{tabular}

Participants were asked which altcoin they knew most. 92.5\% said that they knew nothing about altcoins. However, a minute $7.5 \%$ mentioned that they knew Ethereum. This shows that most participants have little or no knowledge of altcoins that include Etherium. This is again a sign that the participants need to be taught on altcoins.

Table 14: Keen to learn

\begin{tabular}{ccc|r|r|r} 
& & & & \multicolumn{2}{c}{$\begin{array}{c}\text { Cumulative } \\
\text { Percent }\end{array}$} \\
\hline Valid & Frequency & Percent & Valid Percent & 3.8 \\
\cline { 2 - 6 } & 0 & 10 & 3.8 & 3.8 & 13.2 \\
\cline { 2 - 6 } & No & 25 & 9.4 & 9.4 & 39.5 \\
\cline { 2 - 6 } & Maybe & 70 & 26.3 & 26.3 & 72.9 \\
\cline { 2 - 6 } & Yes & 89 & 33.5 & 33.5 & 100.0 \\
\cline { 2 - 6 } & Definitely & 72 & 27.1 & 27.1 & \\
\cline { 2 - 6 } & Total & 266 & 100.0 & 100.0 & \\
\hline
\end{tabular}

Participants were asked whether they were keen to learn about blockchain technology and to use it. Table 14 shows that $60.6 \%$ of the participants are keen to learn about blockchain and to use it. Approximately $26.3 \%$ of the participants say that maybe they might be interested. This is a good reason for higher education institutions to introduce the teaching of blockchain and cryptocurrency, seeing that there is an appetite for it. This supports Luhanga (2020) and Ølnes and Knutsen, (2020) who suggested that it is time for teaching blockchain technology in business schools. 
Table 15: Starting investment in bitcoin

\begin{tabular}{ccr|r|r|r} 
& & & & \multicolumn{2}{c}{$\begin{array}{c}\text { Cumulative } \\
\text { Percent }\end{array}$} \\
\hline Valid & Frequency & Percent & Valid Percent & 14.7 \\
\cline { 2 - 6 } & 0 & 39 & 14.7 & 14.7 & 62.8 \\
\cline { 2 - 6 } & P1000 or less & 128 & 48.1 & 48.1 & 81.6 \\
\hline P1001 to P2000 & 50 & 18.8 & 18.8 & 90.6 \\
\hline & P2001 to P5000 & 24 & 9.0 & 9.0 & 99.2 \\
\hline & Other & 23 & 8.6 & 8.6 & 100.0 \\
\hline 5 & 2 & .8 & .8 & \\
\hline
\end{tabular}

Participants were asked how much money they would be keen to start with investing in bitcoin. Table 15 shows that $48.1 \%$ of the participants would like to start with an investment of P1000 or less. This might be because they are beginners, they wish to minimize losses.

Table 16: Blockchain solution

\begin{tabular}{rcr|r|r|r} 
& & & & \multicolumn{2}{c}{$\begin{array}{c}\text { Cumulative } \\
\text { Percent }\end{array}$} \\
\hline Valid & Frequency & Percent & Valid Percent & 4.5 \\
\cline { 2 - 6 } & 0 & 12 & 4.5 & 4.5 & 11.7 \\
\cline { 2 - 6 } & No & 19 & 7.1 & 7.1 & 47.0 \\
\cline { 2 - 6 } & Maybe & 94 & 35.3 & 35.3 & 87.2 \\
\cline { 2 - 6 } & Yes & 107 & 40.2 & 40.2 & 100.0 \\
\hline & Definitely & 34 & 12.8 & 12.8 & \\
\hline & Total & 266 & 100.0 & 100.0 & \\
\hline
\end{tabular}

Participants were asked whether they think blockchain technology could help solve problems in industry. According to Table 16, 63.0\% of the participants are in the affirmative, while 35.3 say that maybe it will work. There is a positive attitude from the participants pertaining to blockchain solutions. This is supported by Luhanga (2020) who carried out a study in Tanzania which suggested that business schools should teach blockchain technology.

Table 17: Any organization

\begin{tabular}{rrr|r|r|r} 
& \multicolumn{2}{c}{} & \multicolumn{2}{c}{} & \multicolumn{2}{c}{$\begin{array}{c}\text { Cumulative } \\
\text { Percent }\end{array}$} \\
\hline \multirow{3}{*}{ Valid } & \multicolumn{2}{c}{ Frequency } & Percent & Valid Percent & 2.3 \\
\cline { 2 - 6 } & 0 & 6 & 2.3 & 2.3 & 90.2 \\
\cline { 2 - 6 } & No & 234 & 88.0 & 88.0 & 100.0 \\
\cline { 2 - 6 } & Maybe & 26 & 9.8 & 9.8 & \\
\hline
\end{tabular}

Participants were asked whether they knew any organization using blockchain technology and/or cryptocurrency in Botswana. According to Table 17, 88\% said no to the question. This indicates that the participants are not conversant with block chain technology, which may also suggest that 
blockchain technology is not yet abundantly used by organizations in Botswana.

Table 18: Future of blockchain

\begin{tabular}{|c|c|c|c|c|c|}
\hline & & Frequency & Percent & Valid Percent & $\begin{array}{c}\text { Cumulative } \\
\text { Percent }\end{array}$ \\
\hline \multirow[t]{5}{*}{ Valid } & 0 & 20 & 7.5 & 7.5 & 7.5 \\
\hline & No & 34 & 12.8 & 12.8 & 20.3 \\
\hline & Maybe & 146 & 54.9 & 54.9 & 75.2 \\
\hline & Yes & 66 & 24.8 & 24.8 & 100.0 \\
\hline & Total & 266 & 100.0 & 100.0 & \\
\hline
\end{tabular}

Participants were asked whether in future they saw blockchain technology and cryptocurrency transforming the way banks operate and how business is done in Botswana. In Table 18, 54.9\% said maybe, while 24.8\% said yes. This is a sign that there is hope for blockchain technology. This supports Luhanga (2020) and Ølnes \& Knutsen (2020) who suggested that it is time for teaching blockchain technology in business schools.

\section{Conclusion and Recommendations}

The study has shown that most college students generally know nothing about blockchain, and they know very little about altcoins. However, the findings show that university students are optimistic that teaching of blockchain technology and cryptocurrencies could make a huge difference to students and to the economy.

It is therefore recommended that business schools should come up with a syllabus that teaches blockchain technology and cryptocurrencies. Additionally, instead of having a standalone syllabus, some of the materials on blockchain technology and cryptocurrencies could be included in some already existing modules across various programmes that teach business management, insurance, finance and banking, accounting and finance, and entrepreneurship.

The study's main contributions include ensuring that business school students' curricula are enriched with blockchain technology and cryptocurrency, which prepares students for the new world of technology. Furthermore, this makes business schools to be more agile and contemporary, hence making a difference in society, while at the same making more profits from students seeking modern knowledge. Additionally, with scarcity of studies on blockchain technology in Botswana, the study adds to the body of knowledge on that field. 


\section{References:}

1. Austin, J. H. (1998). Zen and the brain: Toward an understanding of meditation and consciousness. Cambridge, MA: MIT Press.

2. Batkins, S. and Brannon, I. (2013). The unknown costs of DoddFrank. Regulation, 36, p.4.

3. Bheemaiah, K. (2015). Why business schools need to teach about the blockchain. Available at SSRN 2596465.

4. Blackman, T. (2017). The Comprehensive University: an alternative to social stratification by academic selection. Higher Education Policy Institute.

5. Bracey, E.N. (2017). The significance of Historically Black Colleges and Universities (HBCUs) in the 21st century: Will such institutions of higher learning survive? American Journal of Economics and Sociology, 76(3), pp.670-696.

6. Busher, J., Choudhury, T., Thomas, P. and Harris, G. (2017). What the Prevent duty means for schools and colleges in England: An analysis of educationalists' experiences.

7. Clohessy, T., Treiblmaier, H., Acton, T. and Rogers, N. (2020). Antecedents of blockchain adoption: An integrative framework. Strategic Change, 29(5), pp.501-515.

8. Crandall, J. (2019). Blockchains and the "Chains of Empire": Contextualizing blockchain, cryptocurrency, and neoliberalism in Puerto Rico. Design and Culture, 11(3), pp.279-300.

9. Crosby, M., Pattanayak, P., Verma, S. and Kalyanaraman, V. (2016). Blockchain technology: Beyond bitcoin. Applied Innovation, 2(6-10), p.71.

10. Deshpande, A., Stewart, K., Lepetit, L. and Gunashekar, S. (2017). Distributed Ledger Technologies/Blockchain: Challenges, opportunities, and the prospects for standards. Overview report The British Standards Institution (BSI).

11. Dettling, W. (2018). How to teach blockchain in a business school. In Business Information Systems and Technology 4.0 (pp. 213-225). Springer, Cham.

12. Fanning, K. and Centers, D.P. (2016). Blockchain and its coming impact on financial services. Journal of Corporate Accounting \& Finance, 27(5), pp.53-57.

13. Fosso Wamba, S., Kala Kamdjoug, J.R., Epie Bawack, R. and Keogh, J.G. (2020). Bitcoin, Blockchain and Fintech: a systematic review and case studies in the supply chain. Production Planning \& Control, 31(2-3), pp.115-142.

14. Kakushadze, Z. and Yu, W. (2019). Altcoin-Bitcoin Arbitrage. arXiv preprint arXiv:1903.06033. 
15. Korpela, K., Hallikas, J. and Dahlberg, T. (2017). January. Digital supply chain transformation toward blockchain integration. In proceedings of the 50th Hawaii international conference on

16. Kumaresh, S. (2021). Academic Blockchain: An Application of Blockchain Technology in Education System. In Data Management, Analytics, and Innovation (pp. 435-448). Springer, Singapore.

17. Lemieux, P. (2013). Who Is Satoshi Nakamoto? Regulation, 36(3), p.14.

18. Lizcano, D., Lara, J.A., White, B. and Aljawarneh, S. (2020). Blockchain-based approach to create a model of trust in open and ubiquitous higher education. Journal of Computing in Higher Education, 32(1), pp.109-134.

19. Luhanga, M.L. (2020). WHY BUSINESS SCHOOLS IN TANZANIA SHOULD TEACH BLOCK CHAIN TECHNOLOGY. Uongozi Journal of Management and Development Dynamics, 30(1).

20. Mainelli, M. and Smith, M. (2015). Sharing ledgers for sharing economies: an exploration of mutual distributed ledgers (aka blockchain technology). Journal of Financial Perspectives, 3(3).

21. Nakamoto, S. (2008). Bitcoin: A peer-to-peer electronic cash system. (Accessed, 9 March 2019) Available: https://s3.amazonaws.com/academia.edu.documents/54517945/Bitcoi n_paper_Original_2.pdf?AWSAccessKeyId=AKIAIWOWYYGZ2Y 53UL3A\&Expires $=1552134775 \&$ Signature $=9 \mathrm{Dc} \% 2 \mathrm{Bt} 0 \mathrm{fMxPcH} 9 \mathrm{dM}$ UeWNyKlFIzBY\%3D\&response-contentdisposition=inline\%3B\%20filename\%3DBitcoin_A_Peer-toPeer_Electronic_Cash_S.pdf

22. Negash, S. and Thomas, D. (2019), May. Teaching blockchain for business. In 2019 IEEE Canadian Conference of Electrical and Computer Engineering (CCECE) (pp. 1-4). IEEE.

23. Nguyen, T.V.H., Nguyen, B.T., Nguyen, T.C. and Nguyen, Q.Q. (2019). Bitcoin return: Impacts from the introduction of new altcoins. Research in International Business and Finance, 48, pp.420425.

24. Ølnes, S. and Knutsen, S.J. (2020). Blockchain Technology in Education-The Challenge of Interdisciplinary Teaching. In Digital samhandling (pp. 373-389).

25. Risius, M. and Spohrer, K. (2017). A blockchain research framework. Business \& Information Systems Engineering, 59(6), pp.385-409.

26. Saunders, M., Lewis P and Thornhill A. (2019). Research methods for business students. Eighth edition. London: Pearson. 
27. Toufaily, E., Zalan, T. and Dhaou, S.B. (2021). A framework of blockchain technology adoption: An investigation of challenges and expected value. Information \& Management, 58(3), p.103444.

28. Willcocks, L. (2020). Robo-Apocalypse cancelled? Reframing the automation and future of work debate. Journal of Information Technology, 35(4), pp.286-302.

29. Wired Horizon (2016) Move over Bitcoin, the blockchain is only just getting started. (Accessed, 9 March 2019) Available here: https://www.wired.co.uk/article/unlock-the-blockchain

30. Wüst, K. and Gervais, A. (2018) June. Do you need a Blockchain? In 2018 Crypto Valley Conference on Blockchain Technology (CVCBT) (pp. 45-54). IEEE.

31. Wiklund, J., Wright, M. and Zahra, S.A. (2019). Conquering relevance: Entrepreneurship research's grand challenge.

32. Ye, C., Ojukwu, C., Hsu, A. and Hu, R. (2020). Alt-Coin Traceability. IACR Cryptol. ePrint Arch., 2020, p.593. 